Kocaeli Journal of Science and Engineering

\title{
Development of Personal Protective Respirator Based on Additive Manufacturing Technologies in Fighting Against Pandemic
}

\author{
Levent AYDIN ${ }^{1, *}$ (D) , Sumeyya ILKIN ${ }^{2}$ (D) , Mehmet Onur ARICAN ${ }^{3}$ (iD), Ayfer Peker KARATOPRAK ${ }^{4}$ (iD , \\ Suhap SAHIN ${ }^{5}$ (D) , Guralp OZKOC ${ }^{6}$ (iD) , Maksut Gorkem AKSU ${ }^{7}$ (iD), Serdar KUCUK $^{8}$ (iD), \\ Ozcan GUNDOGDU ${ }^{9}$ \\ ${ }^{1}$ Podology Program, Vocational School of Kocaeli Health Services, Kocaeli University, Kocaeli,41001, Turkey, ORCID: 0000-0002-2372-1711 \\ ${ }^{2}$ Department of Computer Engineering, Kocaeli University, Kocaeli, 41001, Turkey, ORCID: 0000-0002-0570-2250 \\ ${ }^{3}$ Department of Polymer Science and Technology, Kocaeli University, Kocaeli, 41001, Turkey, ORCID: 0000-0003-3776-9174 \\ ${ }^{4}$ Podology Program, Vocational School of Kocaeli Health Services, Kocaeli University, Kocaeli,41001, Turkey, ORCID: 0000-0003-1723-2038 \\ ${ }^{5}$ Department of Computer Engineering, Kocaeli University, Kocaeli, 41001, Turkey, ORCID: 0000-0003-1340-8972 \\ ${ }^{6}$ Department of Chemical Engineering and Polymer Science and Technology, Kocaeli University, Kocaeli, 41001, Turkey, ORCID: 0000-0002-3194-5256 \\ ${ }^{7}$ Department of Radiation Oncology, Kocaeli University, Kocaeli, 41001, Turkey, ORCID: 0000-0001-5532-2742 \\ ${ }^{8}$ Department of Biomedical Engineering, Kocaeli University, Kocaeli, 41001, Turkey, ORCID: 0000-0002-5543-7539 \\ ${ }^{9}$ Department of Biomedical Engineering, Kocaeli University, Kocaeli, 41001, Turkey, ORCID: 0000-0003-0171-3179
}

Article Info

Research paper

Received : November 29, 2020

Accepted : January 27, 2021

\section{Abstract}

Flexible manufacturing systems have been widely used especially in the field of medicine to develop personal protective types of equipment such as ventilator components or sample collection apparatuses except the face visors and masks/respirators during the fight against the pandemic. In this study, an N95 derivative respirator was designed based on the FDM technology and then compared with similar known mask models in literature in terms of manufacturing costs and functionality. Optimization was carried out on printing parameters to improve the speed of manufacturing. Finally, all components of the mask were assembled and prepared to be used for medical needs during the pandemic. The cost of the mask and filter components were reduced to $7 €$ for 2 hours and 32 minutes for each mask. Moreover, the durability of each mask was increased three times more than known protective types of equipment to offer longer usage without any fractures caused by daily activities and to have improved airtightness. Besides, the mask was designed to have multi-layered filters with the ability of replaceable membranes according to the epidemic agent, and the sterilization procedures were explained. Thus, a more economical and healthier protective equipment was created compared to the known respirators in the literature.

\section{Introduction}

The disease of Covid-19 (Coronavirus) was first detected in Wuhan in December 2019. It has turned into a pandemic in early 2020 that reached 26 million cases causing more than 864 thousand deaths in 188 countries [1-2]. While the most common symptoms of the disease are known as fever and dry cough, there are also less frequent symptoms such as pain and diarrhea. For patients with worsening conditions, respiratory distress and

\footnotetext{
${ }^{*}$ Corresponding Author: levent.aydin@ kocaeli.edu.tr
}

shortness of breath occur and may require urgent medical assistance such as intubation or oxygen therapy. In addition, patients with diffuse pneumonia findings on chest radiography or tomography are isolated in intensive care units and need to be treated according to a specific algorithm [3]. With the onset of the pandemic, both patients and healthcare workers needed a lot of protective equipment, and it was not possible for every center to meet these requirements. Many different applications such as ventilator components or sample collection apparatus, protective equipment (i.e., visors and respirators), which can be easily produced via flexible manufacturing systems, were used to fight against the pandemic [4]. In particular, Fused Deposition Modelling (FDM) based additive 
manufacturing systems were widely used in the production of such equipment and component due to their costeffectiveness. At the beginning phase of the pandemic, rapid solutions were required to be addressed with regards to crisis management based on health priority [5]. Since these manufactured equipment types were used by many people in health centers and hospitals, where they both have high-risk factors, the protection and functionality were not known well leading to create significant risks [6]. For this reason, some definitions and standards for the development of protective equipment based on additive manufacturing technologies have been determined by the authorized organizations (i.e., FDA, CDC, NIH). The Food and Drug Administration (FDA) has recently stated that 3D printed personal protective equipment (PPE) cannot provide one-to-one protection compared to FDA-approved masks. On the other hand, guidelines on $3 \mathrm{D}$ printable devices for emergency use such as ventilator components have been published by FDA [7]. Likewise, the Centers for Disease Control and Prevention (CDC) did not approve homemade face protectors in the category of PPE [8]. However, the National Institutes of Health (NIH) together with the FDA created an online repository for developable PPE prototypes based on additive manufacturing technologies but reported safety limitations due to differences in 3D printing systems, production parameters, and polymer materials used in manufacturing [9]. Although its reliability is questionable, during the pandemic, additive manufacturing technologies-based visors, masks/respirators, goggles, breathing apparatus, and laryngoscope production have been beneficial because a huge equipment need has been met significantly [10-12]. In this scope, it is necessary to know the properties of the equipments used, to ensure the functionality and protection of the products developed and to establish more ergonomic equipment for long-term usage. In addition, it is important to minimize the manufacturing time and cost in order to provide widespread effective protection. Specifically for N95-derived respirators, filters, and filter membrane porosity are important not only for sterilization but also for effectiveness and reusability. Considering these factors, the development of PPE, based on additive manufacturing technologies, gains great importance during the pandemic. Hence, many additive manufacturing methods were utilized in PPE production such as Direct Metal Laser Sintering (DMLS), Selective Laser Sintering (SLS), Fused Deposition Modelling (FDM), and Stereolithography (SLA) methods. FDM method-based equipment manufacturing is more widely used than other additive manufacturing technologies due to its low cost and feasibility [13-15]. Mostly PLA (Polylactic Acid), ABS (Acrylonitrile Butadiene Styrene), PC (Polycarbonate), PETG (Polyethylene Terephthalate Glycol), and various composite polymers are used during the manufacturing [16-17].

In the FDM method, the printing process is carried out by melting and extruding a thermoplastic polymer to form the target object on a printing table. In this scope, the target three-dimensional (3D) model is first divided into transverse 2D (two-dimensional) sections with a slicing software, and then derived G-Codes (machine codes) determine the system behavior until manufacturing is complete. Instant solidification of the molten thermoplastic polymer is provided by a fan during this printing process. However, the nozzle can be clogged due to the burnt polymer residues during printing [18]. Excessive application of the airflow that provides solidification may cause instant solidification of the molten polymer in the nozzle. For these significant and inevitable reasons, these systems must be well calibrated before printing.

Today, there are various defined standards for respirators and filter membranes. Although these standards are named differently according to the countries, they specify the same functionality and mostly express particle permeability efficiency with a minimum size of $0.3 \mu$ [19]. The respirators are named as N95, N99, and N100 in the United States, and as KN90, KN95, and KN100 in China, the numbers defined next to the letters together express the percentage efficiency at a particle permeability of $0.3 \mu$ [20]. Consequently, N95 and KN95 have the same functionality and have particle retention of $0.3 \mu$ at $95 \%$. In Europe, particle permeability has been determined as FFP1 (P1), FFP2 (P2), and FFP3 (P3), and it means filtering efficiency at $80 \%, 94 \%$, and $99.95 \%$, respectively [21]. In addition, the MERV (Minimum Efficiency Rating Value) standard was developed to define the filter efficiency and graded between 1 and 17 as shown in Table 1. MERV standard is based on particle permeability in three different size that range between $(3.0-10.0 \mu, 1.0-3,0 \mu$, and 0.3 $1.0 \mu$ ) are also categorized in Table 1 [22-23].

In Table 1, it is observed that MERV 17 filter group has 99\% retention in the $0.3-1.0 \mu$ particle size band, while the MERV 13-16 filter group has less than 95\% retention in the same particle size band. Accordingly, it is understood that the HEPA (High-Efficiency Particulate Arresting) filter group provides better protection than the Superior MERV filter group. Therefore, considering the spread rate of the virus during the pandemic, the use of HEPA Group filters in PPE development becomes even more important. It has not been possible in all cases to supply these filter membranes, which are used especially in the production of N95-derived respirators, at the beginning of the pandemic. Hence, a need was raised to prefer or develop alternative membranes. In line with this requirement, researchers have developed filter membranes with a certain porosity by means of electrospinning 
methods [24-26]. On the other hand, vacuum cleaner filters were determined as suitable owing to the standard manufacturing and procurable especially at the beginning of the pandemic. Table 2 contains statements regarding HEPA filter groups and their activities [27-28].

Table 1. MERV filter membrane standards [22-23].

\begin{tabular}{|c|c|c|c|c|c|}
\hline Catalog No & $\begin{array}{l}0.3-1.0 \\
\text { micron }\end{array}$ & $\begin{array}{c}1-3 \\
\text { micron }\end{array}$ & $\begin{array}{c}\text { 3-10 } \\
\text { micron }\end{array}$ & Filter Type & Controlled Particles \\
\hline MERV 1 & - & - & $<20 \%$ & \multirow{4}{*}{ Pre-Filter/Aluminum mesh } & \multirow{4}{*}{$\begin{array}{l}\text { Dust, dust mites, animal dander, } \\
\text { pollen }\end{array}$} \\
\hline MERV 2 & - & - & $<20 \%$ & & \\
\hline MERV 3 & - & - & $<20 \%$ & & \\
\hline MERV 4 & - & - & $<20 \%$ & & \\
\hline MERV 5 & - & - & $20-34 \%$ & \multirow{4}{*}{ Low Quality MERV Filter } & \multirow{4}{*}{$\begin{array}{l}\text { Mildew, spores, baking soda, } \\
\text { hair spray }\end{array}$} \\
\hline MERV 6 & - & - & $35-49 \%$ & & \\
\hline MERV 7 & - & - & $50-69 \%$ & & \\
\hline MERV 8 & - & $<20 \%$ & $<70 \%$ & & \\
\hline MERV 9 & - & $<35 \%$ & $<35 \%$ & \multirow{4}{*}{ Standard MERV Filter } & \multirow{4}{*}{$\begin{array}{l}\text { Lead dust, smaller mold, smaller } \\
\text { pollen }\end{array}$} \\
\hline MERV 10 & - & $50-64 \%$ & $<75 \%$ & & \\
\hline MERV 11 & $<20 \%$ & $65-79 \%$ & $<80 \%$ & & \\
\hline MERV 12 & $<35 \%$ & $80 \%$ & $<85 \%$ & & \\
\hline MERV 13 & $<50 \%$ & $<90 \%$ & $<90 \%$ & \multirow{4}{*}{ Superior MERV Filter } & \multirow{4}{*}{ Bacteria, virus, fine dust } \\
\hline MERV 14 & $75-84 \%$ & $<90 \%$ & $<90 \%$ & & \\
\hline MERV 15 & $85-94 \%$ & $<90 \%$ & $<90 \%$ & & \\
\hline MERV 16 & $<95 \%$ & $<95 \%$ & $<95 \%$ & & \\
\hline MERV 17 & $99.97000 \%$ & $<99 \%$ & $<99 \%$ & HEPA Group/ULPA Filter & Little bacteria and viruses, fumes \\
\hline
\end{tabular}

Table 2. HEPA filter membrane standards [27-28].

\begin{tabular}{|c|c|c|c|c|c|}
\hline Usage & Class & Performance & Performance Test & $\begin{array}{c}100 \% \text { Retained } \\
\text { Particle Size }\end{array}$ & Test Standard \\
\hline \multirow{4}{*}{$\begin{array}{l}\text { Coarse filters } \\
\text { (preferred as } \\
\text { a primary } \\
\text { filter) }\end{array}$} & G1 & $65 \%$ & Average value & \multirow{4}{*}{$\begin{array}{l}>5 \mu \mathrm{m} \\
>5 \mu \mathrm{m} \\
>5 \mu \mathrm{m} \\
>5 \mu \mathrm{m}\end{array}$} & \multirow{4}{*}{$\begin{array}{l}\text { BS EN779 } \\
\text { BS EN779 } \\
\text { BS EN779 } \\
\text { BS EN779 }\end{array}$} \\
\hline & G2 & $65-80 \%$ & Average value & & \\
\hline & G3 & $80-90 \%$ & Average value & & \\
\hline & G4 & $90 \%-$ & Average value & & \\
\hline \multirow{5}{*}{$\begin{array}{l}\text { Fine filters } \\
\text { (preferred as } \\
\text { a secondary } \\
\text { filter) }\end{array}$} & M5 & $40-60 \%$ & Average value & \multirow{4}{*}{$\begin{array}{l}>5 \mu \mathrm{m} \\
>2 \mu \mathrm{m} \\
>2 \mu \mathrm{m} \\
>1 \mu \mathrm{m}\end{array}$} & \multirow{4}{*}{$\begin{array}{l}\text { BS EN779 } \\
\text { BS EN779 } \\
\text { BS EN779 } \\
\text { BS EN779 }\end{array}$} \\
\hline & M6 & $60-80 \%$ & Average value & & \\
\hline & F7 & $80-90 \%$ & Average value & & \\
\hline & F8 & $90-95 \%$ & Average value & & \\
\hline & F9 & $95 \%-$ & Average value & \multirow{4}{*}{$\begin{array}{l}>1 \mu \mathrm{m} \\
>1 \mu \mathrm{m} \\
>0.5 \mu \mathrm{m} \\
>0.5 \mu \mathrm{m}\end{array}$} & \multirow{4}{*}{$\begin{array}{l}\text { BS EN779 } \\
\text { BS EN1822 } \\
\text { BS EN1822 } \\
\text { BS EN1822 }\end{array}$} \\
\hline \multirow{3}{*}{$\begin{array}{l}\text { Semi HEPA } \\
\text { filters }\end{array}$} & E10 & $85 \%$ & Minimum value & & \\
\hline & E11 & $95 \%$ & Minimum value & & \\
\hline & E12 & $99.5 \%$ & Minimum value & & \\
\hline \multirow{2}{*}{ HEPA filters } & H13 & $99.95 \%$ & Minimum value & \multirow{4}{*}{$\begin{array}{l}>0.3 \mu \mathrm{m} \\
>0.3 \mu \mathrm{m} \\
>0.3 \mu \mathrm{m} \\
>0.3 \mu \mathrm{m}\end{array}$} & \multirow{4}{*}{$\begin{array}{l}\text { BS EN1822 } \\
\text { BS EN1822 } \\
\text { BS EN1822 } \\
\text { BS EN1822 }\end{array}$} \\
\hline & H14 & $99.995 \%$ & Minimum value & & \\
\hline \multirow{3}{*}{ ULPA } & U15 & $99.9995 \%$ & Minimum value & & \\
\hline & U16 & $99.99995 \%$ & Minimum value & & \\
\hline & U17 & $99.999995 \%$ & Minimum value & $>0.3 \mu \mathrm{m}$ & BS EN1822 \\
\hline
\end{tabular}

According to Table 2, class, performance in percentage, performance test, particle size retained in percentage, and related test standard information are given for each filter. It can be observed that HEPA13 and HEPA14 filters are used as vacuum filter membranes in HEPA filter groups [29]. Especially HEPA13 filter membranes, which are more cost-effective and easily available, cannot hold 50 in 100.000 particles $(99.95 \%$ efficiency). This filtration ability can also be improved by increasing the existing filter membrane thickness or by using a second filter membrane [30,31]. Thus, the current filtration efficiency can be increased. In addition, during the fight against the pandemic, environment and equipment sterilization are of great importance as PPEs. For this purpose, mobile robots that carrying portable UV-C (Ultraviolet C) lamps with $254 \mathrm{~nm}$ wavelength have been 
developed in some hospitals for equipment and environment sterilization [32]. Likewise, UV-C lighting is known to kill many bacteria and micro-organisms. This light source causes DNA degradation in structures such as Corona and Sars viruses [33]. Although it may cause permanent damage to the skin and eyes, it is recommended to be used as an ideal solution for unmanned environment isolation and equipment sterilization. Parameters such as lamp power and distance are important in the effectiveness of sterilization [33]. Therefore, a sterilization process that is developed as a result of an optimization or a suggested protocol is required to be applied in terms of efficiency. In this study, a respirator mask that can be used as an N95 derivative was designed and manufactured by means of an FDM based system. Before the design of the respirator, other similar models based on the FDM method in the literature, were determined and evaluated. In addition, the manufacturing time and cost of each model was calculated and compared with the developed prototype. Finally, optimization and revisions were applied to minimize manufacturing costs and improve the custom fitting of the developed mask to increase protectiveness. Consequently, PPEs may be manufactured at minimal cost and quickly where material supply is difficult to distribute. Moreover, more effective protection can be ensured for healthcare personnel and all other employees, active in the field during the fight against the coronavirus.

\section{FDM Method Based Personal Protective Masks, Properties, and Production Planning}

Before the manufacturing of the developed N95 derived respirator prototype, existing FDM based models utilized in hospitals and health centers were evaluated in terms of time and cost. In this study, the developed face mask design criteria and components were determined using the obtained data. Commonly used masks during the fight against Covid-19 and their features were listed in Table 3.

Table 3. FDM-based face masks.

\begin{tabular}{|c|c|c|c|c|c|c|}
\hline Ref. & & Image & Designer & Time* & Cost* & Explanation \\
\hline [34] & 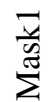 & & $\begin{array}{c}\text { Copper3d } \\
\text { (Open Source) }\end{array}$ & $3 \mathrm{~h} 14 \mathrm{~min}$ & $35 \mathrm{~g}$ & $\begin{array}{l}\text { The model consists of } 3 \text { components. } \\
\text { Printing time and cost are affordable. }\end{array}$ \\
\hline [35] & $\frac{\mathfrak{N}}{\sum^{\mathfrak{J}}}$ & & $\begin{array}{l}\text { LaFactoria3d } \\
\text { (Open Source) }\end{array}$ & $8 \mathrm{~h} 45 \mathrm{~min}$ & $96 \mathrm{~g}$ & $\begin{array}{l}\text { The model consists of } 3 \text { components. } \\
\text { Although the printing time is quite long, } \\
\text { the cost is also a bit high. }\end{array}$ \\
\hline [36] & 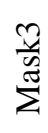 & & $\begin{array}{l}\text { Cagriahiskali } \\
\qquad(10 €)\end{array}$ & 10 h $3 \mathrm{~min}$ & $113 \mathrm{~g}$ & $\begin{array}{l}\text { The model consists of } 3 \text { components. } \\
\text { Although the printing time is quite long, } \\
\text { the cost is also a bit high. }\end{array}$ \\
\hline [37] & 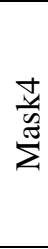 & & $\begin{array}{l}\text { Harnelbe } \\
\qquad(2 €)\end{array}$ & $\begin{array}{c}5 \mathrm{~h} \\
17.3 \mathrm{~min}\end{array}$ & $54.3 \mathrm{~g}$ & $\begin{array}{l}\text { The model consists of } 2 \text { components. It } \\
\text { is not possible to form the model } \\
\text { properly without supporting structures } \\
\text { on a flat table surface. The printing time } \\
\text { is a little longer while the cost is } \\
\text { normal. }\end{array}$ \\
\hline [38] & $\frac{n}{\sum}$ & & $\begin{array}{l}\text { Michaeledi } \\
\text { (Open Source) }\end{array}$ & $3 \mathrm{~h} 24 \mathrm{~min}$ & $35.5 \mathrm{~g}$ & $\begin{array}{l}\text { The model consists of } 3 \text { components. It } \\
\text { is not possible to form the model } \\
\text { properly without supporting structures } \\
\text { on a flat table surface. Printing time and } \\
\text { cost are affordable. }\end{array}$ \\
\hline
\end{tabular}


Table 3. (Cont.) FDM-based face masks.

\begin{tabular}{|c|c|c|c|c|c|c|}
\hline [39] & $\begin{array}{l}\frac{\sigma}{v} \\
\frac{\pi}{\pi} \\
\sum\end{array}$ & 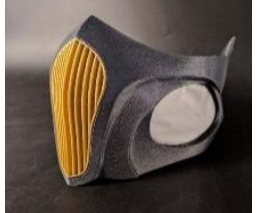 & $\begin{array}{l}\text { 3d-mon } \\
\text { (Open Source) }\end{array}$ & $\begin{array}{c}20 \mathrm{~h} \\
22 \mathrm{~min}\end{array}$ & $212 \mathrm{~g}$ & $\begin{array}{l}\text { The model consists of } 3 \text { components. It } \\
\text { is not possible to form the model } \\
\text { properly without supporting structures } \\
\text { on a flat table surface. The printing time } \\
\text { is quite long, and the cost is very high. }\end{array}$ \\
\hline [40] & $\frac{\pi}{i}$ & & $\begin{array}{l}\text { Aleexstudios_2019 } \\
\qquad(67 €)\end{array}$ & $9 \mathrm{~h} 23 \mathrm{~min}$ & $83.5 \mathrm{~g}$ & $\begin{array}{l}\text { The model consists of } 5 \text { components. } \\
\text { The printing time is quite long, and the } \\
\text { cost is also a bit high. }\end{array}$ \\
\hline [41] & $\begin{array}{l}\infty \\
\frac{1}{N} \\
\sum^{\frac{\pi}{2}}\end{array}$ & & $\begin{array}{l}\text { Stan_x } \\
\text { (Open Source) }\end{array}$ & $4 \mathrm{~h} 39 \mathrm{~min}$ & $47.5 \mathrm{~g}$ & $\begin{array}{l}\text { The model consists of } 2 \text { components. } \\
\text { Printing time and cost are normal. }\end{array}$ \\
\hline [42] & $\frac{\partial}{\frac{\partial}{a}}$ & & $\begin{array}{l}\text { 3dpicasso } \\
(5.517 €)\end{array}$ & $\begin{array}{c}13 \mathrm{~h} \\
45 \mathrm{~min}\end{array}$ & $151 \mathrm{~g}$ & $\begin{array}{l}\text { The model consists of } 3 \text { components. It } \\
\text { is not possible to form the model } \\
\text { properly without supporting structures } \\
\text { on a flat table surface. The printing } \\
\text { time is a bit longer, and the cost is also } \\
\text { a bit high. }\end{array}$ \\
\hline [43] & 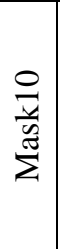 & & $\begin{array}{c}\text { Imalize } \\
\text { (Open Source) }\end{array}$ & $7 \mathrm{~h} 7 \mathrm{~min}$ & $72 \mathrm{~g}$ & $\begin{array}{l}\text { The model consists of } 2 \text { components. It } \\
\text { is not possible to form the model } \\
\text { properly without supporting structures } \\
\text { on a flat table surface. The printing time } \\
\text { is a bit longer, and the cost is also a bit } \\
\text { high. }\end{array}$ \\
\hline [44] & 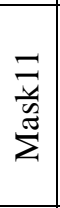 & 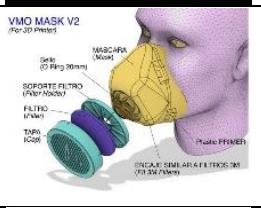 & $\begin{array}{l}\text { Victorottati } \\
\qquad(53 €)\end{array}$ & 8 h $29 \mathrm{~min}$ & $82 \mathrm{~g}$ & $\begin{array}{l}\text { The model consists of } 7 \text { components. It } \\
\text { is not possible to form the model } \\
\text { properly without supporting structures } \\
\text { on a flat table surface. The printing time } \\
\text { is a bit longer, the cost is also a bit high. }\end{array}$ \\
\hline [39] & 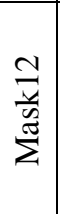 & ynoms & $\begin{array}{l}\text { 3d-mon } \\
\text { (Open Source) }\end{array}$ & $\begin{array}{c}20 \mathrm{~h} \\
22 \mathrm{~min}\end{array}$ & $212 \mathrm{~g}$ & $\begin{array}{l}\text { The model consists of } 3 \text { components. It } \\
\text { is not possible to form the model } \\
\text { properly without supporting structures } \\
\text { on a flat table surface. The printing time } \\
\text { is quite long, and the cost is very high. }\end{array}$ \\
\hline [46] & $\frac{m}{\frac{m}{n}}$ & & $\begin{array}{c}\text { Copper3d } \\
\text { (Open Source) }\end{array}$ & $5 \mathrm{~h} 16 \mathrm{~min}$ & $48 \mathrm{~g}$ & $\begin{array}{l}\text { The model consists of } 3 \text { components. } \\
\text { The printing time is a bit long, but the } \\
\text { manufacturing cost is affordable. }\end{array}$ \\
\hline [47] & 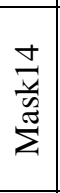 & & $\begin{array}{c}\text { Raimbault_ } \\
\text { Industrie } \\
\text { (Open Source) }\end{array}$ & $\begin{array}{c}19 \mathrm{~h} \\
38 \mathrm{~min}\end{array}$ & $216 \mathrm{~g}$ & $\begin{array}{l}\text { The model consists of } 5 \text { components. } \\
\text { The printing time is quite long, and the } \\
\text { manufacturing cost is also very high. }\end{array}$ \\
\hline [48] & $\frac{n}{\frac{n}{n}}$ & & $\begin{array}{c}\text { Ndreu } \\
\text { (Open Source) }\end{array}$ & $3 \mathrm{~h} 34 \mathrm{~min}$ & $37 \mathrm{~g}$ & $\begin{array}{l}\text { The model consists of } 3 \text { components. It } \\
\text { is not possible to form the model } \\
\text { properly without supporting structures } \\
\text { on a flat table surface. Print time and } \\
\text { cost are normal. }\end{array}$ \\
\hline [49] & 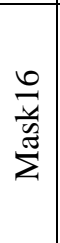 & & $\begin{array}{l}\text { Msa_ } \\
(10 €)\end{array}$ & $9 \mathrm{~h} 19 \mathrm{~min}$ & $103 \mathrm{~g}$ & $\begin{array}{l}\text { The model consists of } 11 \text { components. } \\
\text { It is not possible to form the model } \\
\text { properly without supporting structures } \\
\text { on a flat table surface. The printing time } \\
\text { is quite long, and the manufacturing } \\
\text { cost is quite high. }\end{array}$ \\
\hline
\end{tabular}


Table 3. (Cont.) FDM-based face masks.

\begin{tabular}{|c|c|c|c|c|c|c|}
\hline [50] & $\frac{\bar{z}}{\frac{\pi}{\tilde{J}}}$ & 2) & $\begin{array}{l}\text { Malamaker } \\
\text { (Open Source) }\end{array}$ & $8 \mathrm{~h} 5 \mathrm{~min}$ & $81 \mathrm{~g}$ & $\begin{array}{l}\text { The model consists of } 8 \text { components. } \\
\text { The printing time is long, the } \\
\text { manufacturing cost is also a bit high. } \\
\text { Providing an elastic membrane between } \\
\text { the mask and the face using a mold is } \\
\text { the biggest advantage of the mask. }\end{array}$ \\
\hline [51] & $\frac{\infty}{\sum^{\frac{\pi}{z}}}$ & & $\begin{array}{l}\text { Think3ddd } \\
\text { (Open Source) }\end{array}$ & $8 \mathrm{~h} 42 \mathrm{~min}$ & $102 \mathrm{~g}$ & $\begin{array}{l}\text { The model consists of } 3 \text { components. } \\
\text { The printing time is long, and the } \\
\text { manufacturing cost is also a bit high. }\end{array}$ \\
\hline [52] & $\frac{a}{\frac{a}{\pi}}$ & & $\begin{array}{l}\text { Inhol } \\
\text { (Open Source) }\end{array}$ & 8 h 50 min & $97 \mathrm{~g}$ & $\begin{array}{l}\text { The model consists of } 3 \text { components. } \\
\text { The printing time is long, and the } \\
\text { manufacturing cost is also a bit high. }\end{array}$ \\
\hline
\end{tabular}

* The time and cost calculations specified in the table are valid for only one of a mask manufacturing. In addition, it was determined that 50 grams of material consumption with an average time of 4 hours were normal or affordable in the manufacturing of one mask for an FDM-based system. The evaluations of manufacturing in the table were generated based on this reference.

Ultimaker Cura slicing software was used for the time and cost calculations in Table 3. Printing parameters of each mask model in this calculation step are listed in Table 4.

Table 4. Printing parameters for cost calculation.

\begin{tabular}{|l|l|}
\hline Parameter & Value \\
\hline Nozzle diameter & $400 \mu$ \\
\hline Layer height & $200 \mu$ \\
\hline Inner fill rate & $100 \%$ \\
\hline Inner fill pattern & Line \\
\hline Default print temperature & $200^{\circ} \mathrm{C}$ \\
\hline Default tray temperature & $60{ }^{\circ} \mathrm{C}$ \\
\hline Print speed & $60 \mathrm{~mm} / \mathrm{sec}$ \\
\hline Inner filling print speed & $60 \mathrm{~mm} / \mathrm{sec}$ \\
\hline Wall printing speed & $30 \mathrm{~mm} / \mathrm{sec}$ \\
\hline Top/bottom layer printing speed & $30 \mathrm{~mm} / \mathrm{sec}$ \\
\hline Cooling & Active \\
\hline Support & Close \\
\hline Tray adhesion function & Close \\
\hline
\end{tabular}

The duration of the printing process can be improved by parameters of layer height, internal fill rate, or printing speed. However, in order to clearly determine the cost differences between all models, the ideal manufacturing parameters, that can provide to obtain the target model into a correct geometry as fast as possible, should be taken as reference. Therefore, manufacturing parameters can also be optimized for all mask models. Thus, printing time can be significantly reduced by utilizing the following changes as an example:

- Increasing the layer height from $200 \mu$ to $350 \mu$ depending on the nozzle diameter,

- Increasing the printing speed from $60 \mathrm{~mm} / \mathrm{sec}$ to $120 \mathrm{~mm} / \mathrm{sec}$ depending on the system mechanics,

- Reducing the inner fill rates from $100 \%$ to $30 \%$ in the target model for unnecessary solid regions,

It should be noted that the output must be controlled after each revision in order to ensure the quality of the equipment. In addition, the cost calculations include only the $3 \mathrm{D}$ printed body parts and sub-components but not any filter membrane or fixing apparatuses such as rubber. Table 5 contains the ideal manufacturing plan of different types of equipment as listed in Table 3 (excluding filter membrane and rubber components). The mentioned costs were determined by utilizing the grams spent in manufacturing for ESUN PLA filament $(1 \mathrm{~kg}=100 \mathrm{f})$ and Ultimaker PLA filament $(1 \mathrm{~kg}=480$ €). During this cost calculation build plate of the printer was identified as 220 $\mathrm{mm} / 220 \mathrm{~mm}(\mathrm{X} / \mathrm{Y})$. Each mask model was placed on the same build plate, and printing parameters were fixed for each model. Moreover, their functionalities were evaluated as listed in Table 5. Consequently, basic needs for mask manufacturing were determined according to the results of this evaluation. In this study, an N95 derivative face mask was designed based on the FDM technology and compared with similar known mask models in literature in terms of manufacturing costs and functionality. Furthermore, optimization was carried out on printing parameters to improve the speed of manufacturing. Finally, all components of the mask were assembled and prepared to be used for medical needs during a pandemic. 
Table 5. Manufacturing plan of masks (manufacturing cost of each model was determined in term of Turkish Lira, $€$ ).

\begin{tabular}{|c|c|c|c|c|}
\hline \multicolumn{2}{|c|}{ Image } & \multirow{2}{*}{ Max.* } & \multirow[b]{2}{*}{$\begin{array}{l}\text { Cost* } \\
\text { Esun } \\
3.5 € \\
\text { Ultimaker } \\
16.8 € \\
\end{array}$} & \multirow[b]{2}{*}{$\begin{array}{l}\text { Explanation } \\
\text { Only one mask can be obtained during manufacturing. In addition, the } \\
\text { wall thickness of the model is very thin and it must be manufactured } \\
\text { with a flexible thermoplastic elastomer polymer such as ESUN e- } \\
\text { Lastic. Otherwise, it may break or crack. In addition, it may not fit } \\
\text { every facial anatomy and may require additional rubber components. }\end{array}$} \\
\hline 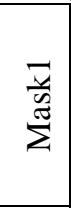 & & & & \\
\hline$\frac{\sum}{\frac{\pi}{\pi}}$ & & $2 \mathrm{pcs}$ & $\begin{array}{l}\text { Esun } \\
9.6 £ \\
\text { Ultimaker } \\
46.08 €\end{array}$ & $\begin{array}{l}\text { Two masks can be obtained during manufacturing. The apparatus used } \\
\text { to fix the filter membrane on the main body of the mask may fall. In } \\
\text { addition, it may not fit every facial anatomy and may require additional } \\
\text { rubber components. }\end{array}$ \\
\hline$\frac{\frac{n}{n}}{\frac{\pi}{\Sigma}}$ & & $2 \mathrm{pcs}$ & $\begin{array}{l}\text { Esun } \\
11.3 € \\
\text { Ultimaker } \\
54.24 €\end{array}$ & $\begin{array}{l}\text { Two masks can be obtained during manufacturing. The apparatus used } \\
\text { to fix the filter membrane on the main body of the mask may fall. In } \\
\text { addition, it may not fit every facial anatomy and may require additional } \\
\text { rubber components. }\end{array}$ \\
\hline $\begin{array}{l}\frac{\nabla}{ \pm} \\
\frac{\pi}{\Sigma}\end{array}$ & & $3 \mathrm{pcs}$ & $\begin{array}{l}\text { Esun } \\
5.43 € \\
\text { Ultimaker } \\
26.064 €\end{array}$ & $\begin{array}{l}\text { Three masks can be obtained during manufacturing. It offers a solid } \\
\text { fixation opportunity with its screwed apparatus. With the dual filter } \\
\text { membrane support, it allows to breathe more easily, but it may not fit } \\
\text { every facial anatomy and may require additional rubber components. } \\
\text { In addition, it is very difficult to manufacture with an FDM-based } \\
\text { system without a support structure. }\end{array}$ \\
\hline 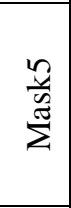 & & $2 \mathrm{pcs}$ & $\begin{array}{l}\text { Esun } \\
3.55 € \\
\text { Ultimaker } \\
17.04 €\end{array}$ & $\begin{array}{l}\text { Two masks can be obtained during manufacturing. The apparatus used } \\
\text { to fix the filter membrane on the main body of the mask may fall. It } \\
\text { may not fit every facial anatomy and may require additional rubber } \\
\text { components. In addition, it is very difficult to manufacture with an } \\
\text { FDM-based system without a support structure. }\end{array}$ \\
\hline 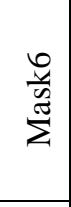 & & $1 \mathrm{pc}$ & $\begin{array}{c}\text { Esun } \\
21.2 € \\
\text { Ultimaker } \\
101.76 £\end{array}$ & $\begin{array}{l}\text { Only one mask can be obtained during manufacturing. The filter } \\
\text { membrane fixing apparatus is relatively thin and It may not fit every } \\
\text { facial anatomy and may require additional rubber components. In } \\
\text { addition, it is very difficult to manufacture with an FDM-based system } \\
\text { without a support structure. }\end{array}$ \\
\hline 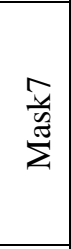 & & $2 \mathrm{pcs}$ & $\begin{array}{l}\text { Esun } \\
8.35 € \\
\text { Ultimaker } \\
40.08 €\end{array}$ & $\begin{array}{l}\text { Two masks can be obtained during manufacturing. It offers a solid } \\
\text { fixation opportunity with its screwed apparatus. With the dual filter } \\
\text { membrane support, it allows to breathe more easily, but it may not fit } \\
\text { every facial anatomy and may require additional rubber components. } \\
\text { In addition, it is very difficult to manufacture with an FDM-based } \\
\text { system without a support structure. }\end{array}$ \\
\hline $\begin{array}{l}\frac{\infty}{0} \\
\frac{\pi}{\Xi} \\
\Sigma\end{array}$ & & $4 \mathrm{pcs}$ & $\begin{array}{l}\text { Esun } \\
4.75 € \\
\text { Ultimaker } \\
22.8 €\end{array}$ & $\begin{array}{l}\text { Four masks can be obtained during manufacturing. The apparatus used } \\
\text { to fix the filter membrane on the main body of the mask may fall. In } \\
\text { addition, it may not fit every facial anatomy and may require additional } \\
\text { rubber components. }\end{array}$ \\
\hline $\begin{array}{l}\frac{\partial}{y} \\
\frac{\pi}{\Sigma}\end{array}$ & & $1 \mathrm{pc}$ & $\begin{array}{l}\text { Esun } \\
15.1 € \\
\text { Ultimaker } \\
72.48 €\end{array}$ & $\begin{array}{l}\text { Only one mask can be obtained during manufacturing. The apparatus } \\
\text { used to fix the filter membrane on the main body of the mask may fall. } \\
\text { It may not fit every facial anatomy and may require additional rubber } \\
\text { components. In addition, it is very difficult to manufacture with an } \\
\text { FDM-based system without a support structure. }\end{array}$ \\
\hline 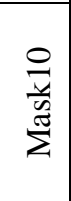 & & $2 \mathrm{pcs}$ & $\begin{array}{l}\text { Esun } \\
7.2 £ \\
\text { Ultimaker } \\
34.56 £\end{array}$ & $\begin{array}{l}\text { Two masks can be obtained during manufacturing. It may not fit every } \\
\text { facial anatomy and may require additional rubber components. In } \\
\text { addition, it is very difficult to manufacture with an FDM-based system } \\
\text { without a support structure. }\end{array}$ \\
\hline 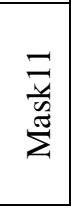 & & $1 \mathrm{pc}$ & $\begin{array}{l}\text { Esun } \\
8.2 £ \\
\text { Ultimaker } \\
39.36 £\end{array}$ & $\begin{array}{l}\text { Only one mask can be obtained during manufacturing. The apparatus } \\
\text { used to fix the filter membrane on the main body of the mask may fall. } \\
\text { It may not fit every facial anatomy and may require additional rubber } \\
\text { components. In addition, it is very difficult to manufacture with an } \\
\text { FDM-based system without a support structure. }\end{array}$ \\
\hline
\end{tabular}


Table 5. (Cont.) Manufacturing plan of masks (manufacturing cost of each model was determined in term of Turkish Lira, €).

\begin{tabular}{|c|c|c|c|c|}
\hline \multicolumn{2}{|c|}{ Image } & Max.* & Cost* & Explanation \\
\hline 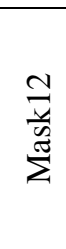 & & $1 \mathrm{pc}$ & $\begin{array}{l}\text { Esun } \\
11.8 \text { } \\
\text { Ultimaker } \\
56.64 \text { 三 }\end{array}$ & $\begin{array}{l}\text { Only one mask can be obtained during manufacturing. The apparatus } \\
\text { used to fix the filter membrane on the main body of the mask may fall. } \\
\text { It may not fit every facial anatomy and may require additional rubber } \\
\text { components. In addition, it is very difficult to manufacture with an } \\
\text { FDM-based system without a support structure. The existing mask } \\
\text { structure consists of too many components. }\end{array}$ \\
\hline$\frac{\frac{m}{\sqrt[n]{n}}}{\sum^{\frac{m}{n}}}$ & & $4 \mathrm{pcs}$ & $\begin{array}{l}\text { Esun } \\
4.8 € \\
\text { Ultimaker } \\
23.04 €\end{array}$ & $\begin{array}{l}\text { Four masks can be obtained during manufacturing. It may not fit every } \\
\text { facial anatomy and may require additional rubber components. }\end{array}$ \\
\hline 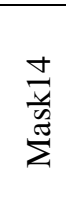 & & $2 \mathrm{pcs}$ & $\begin{array}{c}\text { Esun } \\
21.6 \text { 要 } \\
\text { Ultimaker } \\
103.68 €\end{array}$ & $\begin{array}{l}\text { Two masks can be obtained during manufacturing. The apparatus used } \\
\text { to fix the filter membrane on the main body of the mask may fall. It } \\
\text { may not fit every facial anatomy and may require additional rubber } \\
\text { components. In addition, it is very difficult to manufacture with an } \\
\text { FDM-based system without a support structure. }\end{array}$ \\
\hline$\frac{\frac{n}{\sqrt{n}}}{\frac{\pi}{\tilde{E}}}$ & & $2 \mathrm{pcs}$ & $\begin{array}{l}\text { Esun } \\
3.7 € \\
\text { Ultimaker } \\
17.76 €\end{array}$ & $\begin{array}{l}\text { Two masks can be obtained during manufacturing. It may not fit every } \\
\text { facial anatomy and may require additional rubber components. In } \\
\text { addition, it is very difficult to manufacture with an FDM-based system } \\
\text { without a support structure. }\end{array}$ \\
\hline 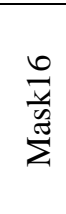 & & $2 \mathrm{pcs}$ & $\begin{array}{l}\text { Esun } \\
10.3 € \\
\text { Ultimaker } \\
49.44 €\end{array}$ & $\begin{array}{l}\text { Two masks can be obtained during manufacturing. It may not fit every } \\
\text { facial anatomy and may require additional rubber components. In } \\
\text { addition, it is very difficult to manufacture with an FDM-based system } \\
\text { without a support structure. The existing mask structure consists of too } \\
\text { many components. }\end{array}$ \\
\hline$\frac{\frac{\pi}{n}}{\frac{\pi}{n}}$ & & $1 \mathrm{pc}$ & $\begin{array}{l}\text { Esun } \\
8.1 € \\
\text { Ultimaker } \\
\text { 38.88 }\end{array}$ & $\begin{array}{l}\text { Only one mask can be obtained during manufacturing. It has a molded } \\
\text { elastic membrane that allows a better custom fitting and prevents } \\
\text { leakage. It is very difficult to manufacture with an FDM-based system } \\
\text { without a support structure. }\end{array}$ \\
\hline 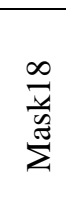 & & $2 \mathrm{pcs}$ & $\begin{array}{l}\text { Esun } \\
10.2 £ \\
\text { Ultimaker } \\
48.96 £\end{array}$ & $\begin{array}{l}\text { Two masks can be obtained during manufacturing. It may not fit every } \\
\text { facial anatomy and may require additional rubber components. }\end{array}$ \\
\hline$\frac{\frac{a}{v}}{\frac{\vec{v}}{\pi}}$ & & $2 \mathrm{pcs}$ & $\begin{array}{l}\text { Esun } \\
19.4 \text { E } \\
\text { Ultimaker } \\
93.12 \text { E }\end{array}$ & $\begin{array}{l}\text { Two masks can be obtained during manufacturing. It may not fit every } \\
\text { facial anatomy and may require additional rubber components. In } \\
\text { addition, it is very difficult to manufacture with an FDM-based system } \\
\text { without a support structure. }\end{array}$ \\
\hline
\end{tabular}

\section{Materials and Methods}

Initially, additive manufactured masks in the literature were evaluated in terms of design, functionality, and manufacturing cost. Considering these features, a costeffective mask model that can use any standard filter membrane and printed quickly without support structures was developed. The main body of the mask was designed in SolidWorks 2019 (Dassault Systemes) workspace.
During the design step, the mask body was manufactured without support structures and developed at sufficient thickness to prevent any leakage. In addition, the filtering process was planned gradually in order to increase protection. Thus, it was possible to filter large particles directly with a pre-filter and smaller particles were collected by a second filter membrane. Figure 1 illustrates the 3D mask model and the sub-components. 


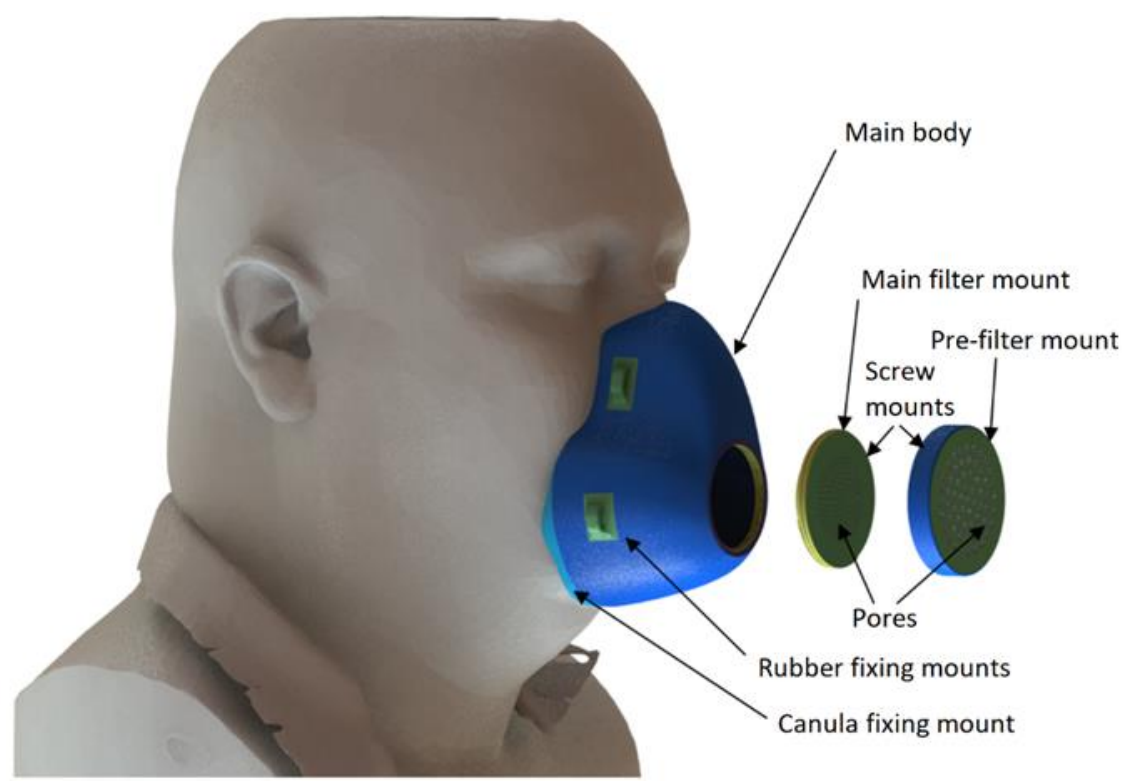

Figure 1. Schematic drawing of the mask model and sub-components.

In the design step, a special filtering apparatus was created according to the gradual filtering process, which can be fixed via screw mounts to create a sealing between the filter apparatus and the main body of the mask. It was planned to provide airflow through $3 \mathrm{~mm}$ holes on the prefiltering apparatus and $500 \mu$ holes on the main filtering apparatus to create a gradual filtration. The circular membrane width to be placed on the filter apparatus was designed as $40 \mathrm{~mm}$ and all components had a thickness of $3 \mathrm{~mm}$ to prevent any cracking or leaking.

The manufacturing plan was made after the final design of the mask model was completed. It was possible to manufacture at least 3 masks at one time, according to the manufacturing scenario that was realized in Ultimaker Cura software, for any FDM-based system with 220 $\mathrm{mm} / 220 \mathrm{~mm}$ build area. Figure 2 illustrates the maximum manufacturing plan of the developed mask model for the $22 \mathrm{~cm}^{2}$ build table. Support structures were not included during this planning in order to save time. Likewise, too much manufacturing at one time by placing the components on top of each other was not included in order to ensure the product quality. Therefore, each component was planned to contact the surface of the build table. Hence, any production risk related to complex geometry, which may prevent the printing process, was avoided. The purpose of this planning with the mentioned criteria was to produce a high protective and healthy equipment in a short time and to deliver as fast as possible for mask users. Figure 2 illustrates the maximum production planning of the 3D mask model and its sub-components.

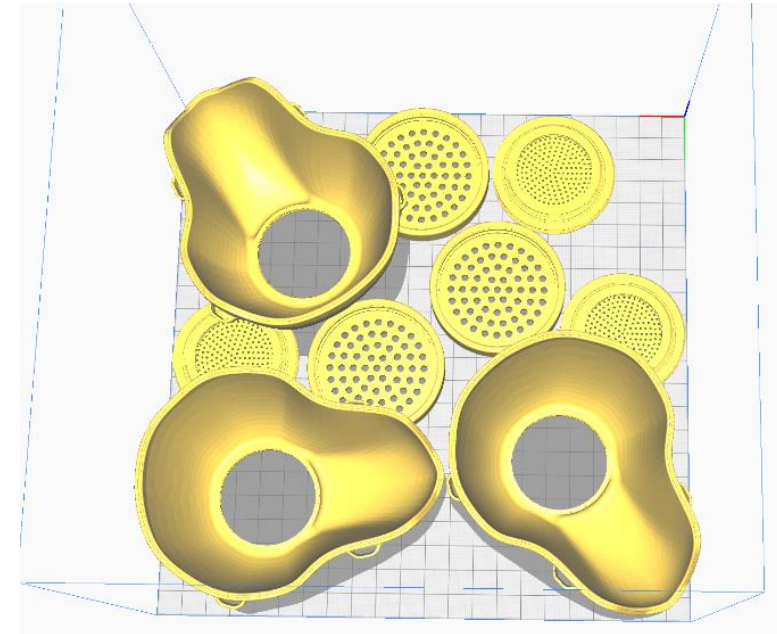

Figure 2. Production planning of the developed mask.

After the production plan, the mask model was manufactured by an FDM based 3D printer (Ender 3 Pro, Creality). Before manufacturing, GCodes were derived by utilizing the parameters given as reference in Table 4, and then the mask was manufactured with ESUN PLA filament. With the completion of the manufacturing process, other sub-components such as rubber and filter membrane were determined. In this context, the mesh density of an existing filter membrane in FFP2 standard and filter membrane in 2 different HEPA13 standards was observed via a microscope (Portable Digital USB microscope 1000X, Ultra-eye-Optics Ltd.) and measured with ImageJ (Fiji) software. It was observed that HEPA13 standard vacuum cleaner filters were cost-effective and can be obtained easier than other FFP3 and FFP2 standard filter membranes especially at the initial stage of the pandemic. For this reason, in this study, it was planned to use 2 layers of a $1000 \mu$ thick HEPA13 standard vacuum 
cleaner (Philips, Marathon) filter as a filter membrane. In addition, nasal cannula tubing was used as a silicone sealing apparatus on the main body of the mask that provides better fitting on any facial anatomy. A rubber, 5 mm wide, oval-shaped, tres knitted rope was preferred for long-term use. After the assembly step, improvements, as given in Table 6, were made to the existing manufacturing process to reduce the time and cost. Finally, ideal manufacturing parameters were determined to obtain the developed protective equipment at a minimal cost.

\section{Results and Discussion}

The manufacturing time of a mask and subcomponents was calculated as 6 hours 55 minutes. The consumable material required for production was also determined as 84 grams. The internal fill rate was reduced to $30 \%$ for regions thicker than $3 \mathrm{~mm}$ on the main body of the mask. Likewise, other manufacturing parameters were revised and determined as ideal for the developed mask as shown in Table 6 . The processing time was reduced to 2 hours 32 minutes and the amount of material to 70 grams by using the parameters given in Table 6 . Thus, masks can be manufactured with a desired thick wall to prevent any deformation during daily usage. As a result, the manufacturing cost of a mask was determined as 7 for ESUN PLA filament, excluding rubber, filter membrane, and sealing component.

Table 6. Optimized printing parameters for the slicer.

\begin{tabular}{|l|l|}
\hline Parameter & Value \\
\hline Layer height & $300 \mu$ \\
\hline Inner fill rate & $30 \%$ \\
\hline Print speed & $120 \mathrm{~mm} / \mathrm{sec}$ \\
\hline Inner filling print speed & $120 \mathrm{~mm} / \mathrm{sec}$ \\
\hline Wall printing speed & $60 \mathrm{~mm} / \mathrm{sec}$ \\
\hline Top/bottom layer printing speed & $60 \mathrm{~mm} / \mathrm{sec}$ \\
\hline
\end{tabular}

Figure 3 illustrates the comparison of the time and costs required for the manufacturing of a mask body and sub-components only.

\section{Cost and Time Cost of Each Mask Model}

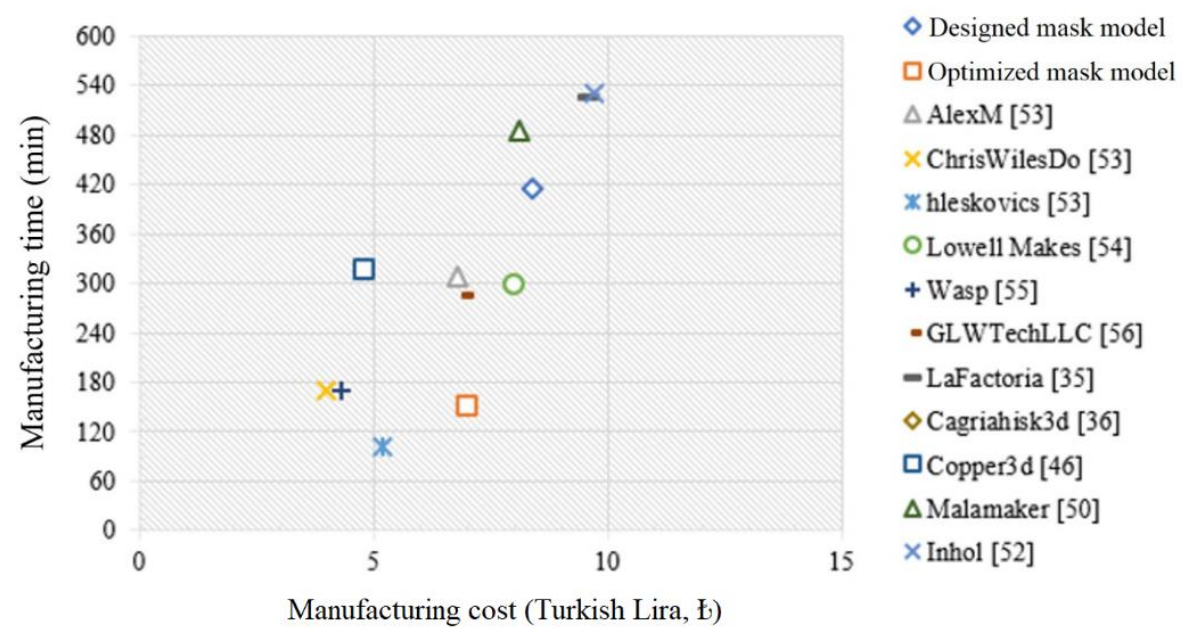

Figure 3. FDM-based production time and costs of N95-derived masks.

According to the porosity measurements of the filter membranes, a standard FFP2 filter membrane (thickness $200 \mu$ ) was determined between $21.4 \mu$ (min.) and $32.6 \mu$ (max.) $(n=5)$. In addition, measurements were performed on two different HEPA13 filter membranes (thickness 1000 $\mu)$ : i) For HEPA13-1 (Philips, Marathon product) it was measured as $19.1 \mu$ (min.) and $43 \mu$ (max.), and ii) For HEPA13-2 (another HEPA13 from a different supplier) it was measured as $40.5 \mu$ (min.) and $55.7 \mu$ (max.) $(\mathrm{n}=5)$. As a result, average porosity of $4.84 \mu$ was determined for a standard FFP2 filter membrane and $5.34 \mu$ for the
HEPA13-2 filter which is close to the FFP2 standard. Figure 4 illustrates the pore sizes of a standard FFP2 filter membrane and two different HEPA13 filters (Philips Marathon vacuum cleaner filter and another HEPA13 filter).

It was determined that 60 filter membranes could be obtained (1000 $\mu$ thick) in a single vacuum cleaner filter and the cost of a filter (Philips, Marathon) was $30 \mathrm{z}$. The total cost of the mask and its components were listed as below:

i) Mask and sub-components - 7£, 
ii) Filter membrane - $0.5 €$,

iii) Sealing apparatus (nasal cannula) - $1.25 €$ and

iv) Rubber - as $0.25 €$. In total, the manufacturing of a whole mask cost 9 E. Figure 5 illustrates the assembled mask prototype.

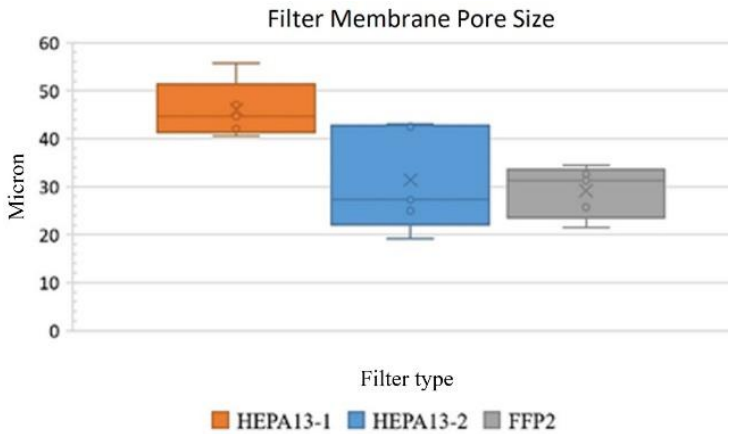

Figure 4. FFP2 and HEPA pore sizes $(n=5)$.

The flexibility of the filament is important especially during the 3D printing of Mask 1 that is given in Tables 3 . In addition, these flexible filaments should not be printed at normal and high speeds [53]. For this reason, masks in this group were excluded from the comparison chart given in Figure 3. Full face masks or masks that have additional eye protection apparatus were also not considered. Apart from these, designs that only cover the mouth and nose, such as Mask 12, have too many components. Hence, their printing time is quite long and their components can cover almost the entire surface of the build plate. On the contrary, it was determined that models with a design such as Mask 17 are more suitable in terms of manufacturing planning and usage. In addition to this planning, the manufacturing costs of each mask model is also important. The current manufacturing time and cost of the Mask 17 is higher (3.19 and 1.1 times, respectively) than the developed mask model in this study. Moreover, the thickness of the mentioned model is 1.5 times less which may affect the durability and tightness.

The thick body structure may increase durability, especially in long-term use. An unwanted leakage, caused by the gaps between perimeters during the $3 \mathrm{D}$ printing process, may occur in models with thinner body structures such as Mask 11. Although the thickness of the body structure extends the printing time, the protection provided by the mask is more important, and thus it's recommended that the thickness value should be a minimum of $2 \mathrm{~mm}$ as a result of this evaluation. It was observed that $1 \mathrm{~mm}$ and thinner models even the separation of the model may crack from the build table after printing.

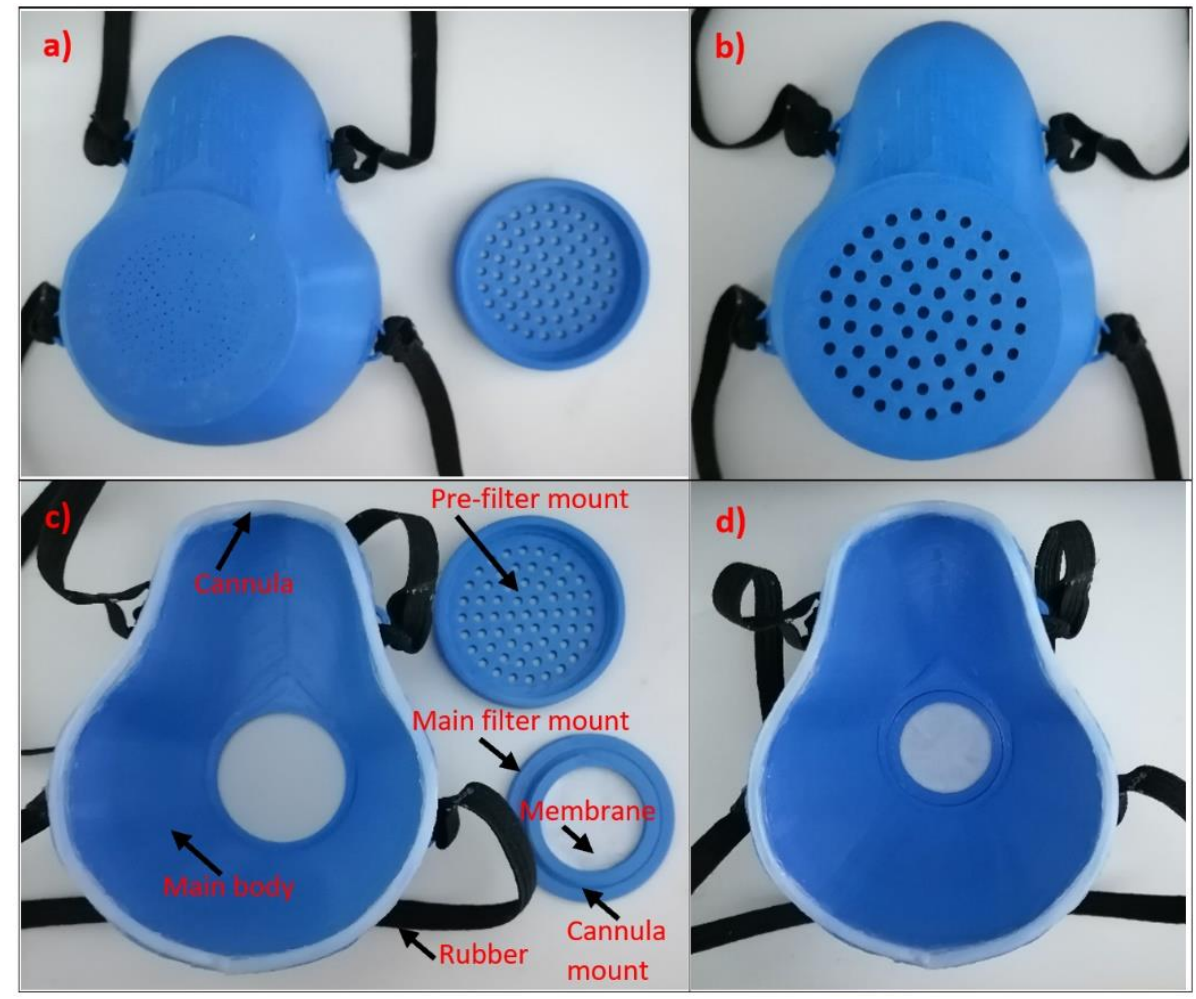

Figure 5. Completed mask prototype. Top view of assembled main filter apparatus only (a) and the assembled main filter and pre-filter apparatus (b). View of all unassembled (c) and assembled components (d). 
Another important parameter is the attachable filter mount apparatus in mask models such as used in Mask 19. This apparatus is designed to be directly attached to the main body of the mask. Therefore, it may deform and may cause leakage during usage after several assemblies. On the other hand, the masks with screw mounts such as Mask 1 and Mask 17 prevent more leakage than the models such as Mask 19. In this study, in order to minimize the unwanted leakage, it was decided to connect the main body of the mask and the filter apparatus by screwing. Moreover, a cannula, a gasket, or a silicone component can be placed into the gap between these two parts to improve tightness. Custom fitting is crucial for each mask to provide better protection. As observed in many mask models except the Mask 3 and Mask 17, the main body structures of the models require to contact directly with the face that may cause skin irritation. As applied in Mask 17, it is recommended to use a silicone or a rubber component between the mask and the face to prevent this discomfort and skin irritation, especially during long-term use. The sealing component must be developed or preferred from a medical-grade material whose effects are well-known.

In addition to the mask design, the type and protection of the used filter membranes are important. Although the Coronavirus sizes are very small, such as 100 $\mathrm{nm}$, protection tests for a standard FFP2 or a HEPA filter are defined as $300 \mathrm{~nm}$ ( $\mathrm{min}$.) particle sizes [57-58]. In this case, the pore sizes of the filter membranes, their thickness, and particle capture capabilities also play a crucial role. These abilities may be grouped as mechanical particle capture capability, other trapping features such as inertia effect, retention, blocking, and diffusion in filter membranes or electrostatic capture that can be created in fibers [59]. Functionality tests of all these features are carried out by experimental or simulation studies to reveal the protection quality of the filter membranes [60]. As a result of this research, it was observed that the HEPA13 filter membrane properties were close to a standard FFP2 filter membrane. However, it should be noted that even commercially available same filter membranes may have different pore sizes. Therefore, it is recommended to perform an experimental study based on the target pathogen sizes before usage.

Although FFP2 or HEPA standards are generally preferred on filter membranes in FDM-based mask prototypes, long-term protection is still uncertain. Even the FFP3 standard, it was determined that filter membranes prevent the risk of infection with an efficiency range of $94 \%$ to $99 \%$ during a 20 -minute inhalation [61]. Therefore, Ultra Hepa Filter (ULPA) group, which is listed in Table 2, is recommended as filter membranes to increase the protectiveness of developed masks.

\section{Conclusions}

In this study, a more reliable, robust, and cheaper respirator was developed to fight against the pandemic. Furthermore, the fundamentals of mask design and manufacturing process were meticulously clarified to ensure the protectiveness of personal equipment. In particular, the manufacturing time and cost of FDM-based masks were significantly decreased. Moreover, the airtightness of the mask was improved via commercially available components

\section{Acknowledgments}

This study was financially supported by BAP Project (FHD-2020-2220) of Kocaeli University.

\section{Conflict of Interests}

No conflict of interest was stated by the authors.

\section{Declaration of Ethical Standards}

The authors of this article declare that the materials and methods used in this study do not require ethical committee permission and legal-special permission.

\section{References}

[1] WHO, 2020. Naming the Coronavirus Disease (COVID-19) And the Virus That Causes It. https://www.who.int/emergencies/diseases/novelcoronavirus-2019/technical-guidance/naming-thecoronavirus-disease-(covid-2019)-and-the-virus-thatcauses-it. (Access Date: 20.11.2020).

[2] Wikipedia, 2020. COVID-19 Pandemic. https://en.wikipedia.org/wiki/COVID-19_pandemic. (Access Date: 20.11.2020).

[3] TR Ministry of Health Scientific Advisory Board Study, 2020. Covid-19 Adult Patient Treatment. http://www.solunum.org.tr/TusadData/userfiles/file/co vid-19_rehberi_eriskin_hasta_tedavisi.pdf. (Access Date: 20.11.2020).

[4] Choong Y.Y.C., Tan H.W., Patel D.C., Choong W.T.N., Chen C.H., Low H.Y., Tan M.J., Patel C.D., Chua C.K., 2020. The Global Rise of 3D Printing During the COVID-19 Pandemic. Nature Reviews Materials 5, pp. 637-639.

[5] Ishack S., Lipner S.R., 2020. Applications of 3D Printing Technology to Address COVID-19 Related Supply Shortages. The American Journal of Medicine 2, pp. 1-14. 
[6] FDA, 2020. FDA's Role in 3D Printing. https://www.fda.gov/medical-devices/3d-printingmedical-devices/fdas-role-3d-printing, (Access Date: 10.10.2020).

[7] Clifton W., Damon A., Martin A.K., 2020. Considerations and Cautions for Three-DimensionalPrinted Personal Protective Equipment in the COVID19 Crisis. 3D Printing and Additive Manufacturing 7, pp. 97-99.

[8] CDC, 2020. Strategies for Optimizing the Supply of Facemasks. https://www.cdc.gov/coronavirus/2019ncov/hcp/ppe-strategy/face-masks.html. (Access Date: 03.04.2020).

[9] NIH, 2020. COVID-19 Supply Chain Response. https://3dprint.nih.gov/collections/covid-19-response. (Access Date: 03.04.2020).

[10]Attaran M., 2020. 3D Printing Role in Filling the Critical Gap in the Medical Supply Chain During COVID-19 Pandemic. American Journal of Industrial and Business Management 10, pp. 988-1001.

[11]Ishack S., Lipner S.R., 2020. Applications of 3D Printing Technology to Address COVID-19 Related Supply Shortages. The American Journal of Medicine 133, pp. 771-773.

[12]Mostaghimi A., Antonini M.J., Plana D., Anderson P.D., Beller B., Boyer E.W., Fannin A., Freake J., Oakley R., Sinna M.S., Smith L., Van C., Yang H., Sorger P.K., LeBoeuf N.R., Yu S.H., 2020. Regulatory and Safety Considerations in Deploying a Locally Fabricated, Reusable Face Shield in a Hospital Responding to the Covid-19 Pandemic. Med 1, pp. 118.

[13]Long J., Gholizadeh H., Lu J., Bunt C., Seyfoddin A., 2017. Application of Fused Deposition Modelling (FDM) Method of 3D Printing in Drug Delivery. Current Pharmaceutical Design 23, pp. 433-439.

[14]Chen M.Y., Skewes J., Woodruff M.A., Dasgupta P., Rukin N.J., 2020. Multi-Colour Extrusion Fused Deposition Modelling: A Low-Cost 3D Printing Method for Anatomical Prostate Cancer Models. Scientific Reports 10, pp. 1-5.

[15]Rengier F., Mehndiratta A., Von Tengg-Kobligk H., Zechmann C., Unterhinninghofen R., Kauczor H., Giesel F., 2010. 3D Printing Based on Imaging Data: Review of Medical Applications. International Journal of Computer Assisted Radiology and Surgery 5, pp. $335-341$.

[16]Ilardo R., Williams C., 2010. Design and Manufacture of a Formula SAE Intake System Using Fused
Deposition Modeling and Fiber-Reinforced Composite Materials. Rapid Prototyping Journal 16, pp. 174-179.

[17]Shofner M., Lozano K., Rodríguez-Macías F., Barrera E., 2003. Nanofiber-Reinforced Polymers Prepared by Fused Deposition Modeling. Journal of Applied Polymer Science 89, pp. 3081-3090.

[18]Heller B., Smith D., Jack D., 2015. The Effects of Extrudate Swell, Nozzle Shape, And the Nozzle Convergence Zone on Fiber Orientation in Fused Deposition Modeling Nozzle Flow. American Society of Composites-30th Technical Conference, Michigan, USA, 28-30 September, pp. 1220-1236.

[19]Neupane B., Giri B., 2020. Current Understanding on the Effectiveness of Face Masks and Respirators to Prevent the Spread of Respiratory Viruses. engrXiv, https://doi.org/10.31224/osf.io/h3wgc.

[20]CDC - NIOSH - Respirator Fact Sheet. Understanding Respiratory Protection Against SARS, https://www.cdc.gov/niosh/npptl/topics/respirators/fact sheets/respsars.html. (Access Date: 03.04.2020).

[21]Wigglesworth N., 2019. Infection Control 5: Equipment for Facial and Respiratory Protection. Nursing Times 10, pp. 30-32.

[22]Deneysan, $2020 . \quad$ Havalandirma. http://deneysan.com/Content/images/documents/haval andirma-3_63272884.pdf. (Access Date: 03.04.2020).

[23]Airfuji, 2020. Hepa Versus MERV Filters. https://airfuji.com/hepa-vs-merv. (Access Date: 10.06.2020).

[24]He H., Gao M., Illés B., Molnar K., 2020. 3D Printed and Electrospun, Transparent, Hierarchical Polylactic Acid Mask Nanoporous Filter. International Journal of Bioprinting 6, pp. 1-9.

[25]Bulus E., Bulus G.S., Yakuphanoglu F., 2020. Production of Polylactic Acid-Activated Charcoal Nanofiber Membranes For COVID-19 Pandemic by Electrospinning Technique and Determination of Filtration Efficiency. Journal of Materials and Electronic Devices 4, pp. 21-26.

[26]Ahmed M.K., Afifi M., Uskoković V., 2020. Protecting Healthcare Workers During COVID-19 Pandemic with Nanotechnology: A Protocol for A New Device from Egypt. Journal of Infection and Public Health 13, pp. 1243-1246.

[27]Wikipedia, $2020 . \quad$ Air $\quad$ Filters. https://en.wikipedia.org/wiki/Air_filter\#Filter_classes. (Access Date: 10.06.2020). 
[28]European Standard EN 1822-1:2009, High Efficiency Air Filters (EPA, HEPA and ULPA). https://standards.iteh.ai/catalog/standards/cen/46f566b 7-2405-4a14-988c-8436402d0975/en-1822-1-2009. (Access Date: 10.06.2020).

[29]Bosch, Elektrikli Süpürgeler. https://www.boschhome.com.tr/urun-listesi/elektrikli-supurgeler/toztorbasiz-elektrikli-supurgeler/BGC41Q69. (Access Date: 20.06 .2020$)$.

[30]Fersan, Hepa Filtre Nedir. https://www.boschhome.com.tr/urun-listesi/elektrikli-supurgeler/toztorbasiz-elektrikli-supurgeler/BGC41Q69. (Access Date: 20.06 .2020 ).

[31]Tcharkhtchi A., Abbasnezhad N., Seydani M.Z., Zirak N., Farzaneh S., Shirinbayan M., 2020. An Overview of Filtration Efficiency Through the Masks: Mechanisms of the Aerosols Penetration. Bioactive Materials 6, pp. 106-122.

[32]BBC, 2020. Coronavirus: Robots Use Light Beams to Zap Hospital Viruses. Journal of Infection and Public Health. https://www.bbc.com/news/business51914722. (Access Date: 08.07.2020).

[33]Darnell M.E., Subbarao K., Feinstone S.M., Taylor D.R., 2004. Inactivation of the Coronavirus That Induces Severe Acute Respiratory Syndrome, SARSCoV. Journal of Virological Methods 121, pp. 85-91.

[34]Cults, 2020. N95 Masks Against Coronavirus - Hack the Pandemic. https://cults3d.com/en/3dmodel/tool/n95-masks-against-coronavirus-covid19hackthepandemic. (Access Date: 10.07.2020).

[35]Cults, 2020. N95 Masks Against Coronavirus - Hack the Pandemic. https://cults3d.com/en/3dmodel/tool/covid-19-mask-easy-to-print-no-supportfilter-required. (Access Date: 10.07.2020).

[36]Cults, 2020. N95 Masks Against Coronavirus - Hack the Pandemic. https://cults3d.com/en/3dmodel/tool/covid-19-mask-easy-to-print-no-supportmodified-version. (Access Date: 10.07.2020).

[37]Cults, 2020. N95 Masks Against Coronavirus - Hack the Pandemic. https://cults3d.com/en/3dmodel/tool/masque-de-protection-covid-19-epiequipement-individuel-de-secours. (Access Date: 10.07.2020).

[38]Cults, 2020. N95 Masks Against Coronavirus - Hack the Pandemic. https://cults3d.com/en/3dmodel/tool/reusable-facial-mask-frame. (Access Date: 10.07.2020).

[39]Cults, 2020. N95 Masks Against Coronavirus - Hack the Pandemic. https://cults3d.com/en/3d- model/fashion/respirator-breathing-mask-with-hepafilter. (Access Date: 10.07.2020).

[40]Cults, 2020. N95 Masks Against Coronavirus - Hack the Pandemic. https://cults3d.com/en/3dmodel/various/mask-antvirus. (Access Date: 10.07.2020).

[41]Cults, 2020. N95 Masks Against Coronavirus - Hack the Pandemic. https://cults3d.com/en/3dmodel/tool/covid-19-mask-easy-to-print-no-supportfilter-required. (Access Date: 10.07.2020).

[42]Cults, 2020. N95 Masks Against Coronavirus - Hack the Pandemic. https://cults3d.com/en/3dmodel/tool/h1-heavy-mask. (Access Date: 10.07.2020).

[43]Cults, 2020. N95 Masks Against Coronavirus - Hack the Pandemic. https://cults3d.com/en/3dmodel/various/masque-fmp-imalize-securite-covid-19facile-a-imprimer-aucun-support-filtre-requis. (Access Date: 10.07.2020).

[44]Cults, 2020. N95 Masks Against Coronavirus - Hack the Pandemic. https://cults3d.com/en/3dmodel/various/vmo-mask-v2-coronavirus-covid-19. (Access Date: 10.07.2020).

[45]Cults, 2020. N95 Masks Against Coronavirus - Hack the Pandemic. https://cults3d.com/en/3dmodel/various/vmo-mask-v3-coronavirus-covid-19improved-version. (Access Date: 10.07.2020).

[46]Cults, 2020. N95 Masks Against Coronavirus - Hack the Pandemic. https://cults3d.com/en/3dmodel/tool/nanohack-2-0-n95-masks-againstcoronavirus-covid19-hackthepandemic. (Access Date: 10.07.2020).

[47]Cults, 2020. N95 Masks Against Coronavirus - Hack the Pandemic. https://cults3d.com/en/3dmodel/tool/masque-ffp2-reel-filtration-covid-19. (Access Date: 10.07.2020).

[48]Cults, 2020. N95 Masks Against Coronavirus - Hack the Pandemic. https://cults3d.com/en/3dmodel/gadget/respirator-mask-removable-filter. (Access Date: 10.07.2020).

[49]Cults, 2020. N95 Masks Against Coronavirus - Hack the Pandemic. https://cults3d.com/en/3dmodel/various/mask-1-n95-with-modular-filters-adultversion. (Access Date: 10.07.2020).

[50]Cults, 2020. N95 Masks Against Coronavirus - Hack the Pandemic. https://cults3d.com/en/3dmodel/various/reusable-mask-ppe-alternativemalamask. (Access Date: 10.07.2020). 
[51]Cults, 2020. N95 Masks Against Coronavirus - Hack the Pandemic. https://cults3d.com/en/3dmodel/various/cov3d-v2-08-fdm-3d-print-optimisedmask-in-15-sizes-also-for-children. (Access Date: 10.07.2020).

[52]Cults, 2020. N95 Masks Against Coronavirus - Hack the Pandemic. https://cults3d.com/en/3dmodel/tool/another-cap-for-covid-19-mask. (Access Date: 10.07.2020).

[53]Novak J.I., Loy J., 2020. A Quantitative Analysis Of 3D Printed Face Shields and Masks During COVID19. Emerald Open Research 2, pp. 1-14.

[54]Tino R., Moore R., Antoline S., Ravi P., Wake N., Ionita C.N., Morris J.M., Decker S.J., Sheikh A., Rybicki F.J., Chepelev, L.L., 2020. COVID-19 and the role of $3 \mathrm{D}$ printing in medicine. 3D Printing in Medicine 6, pp. 1-8.

[55]WASP, 2020. 3D Printed Mask From 3D Scanning. https://www.3dwasp.com/en/3d-printed-mask-from3d-scanning. (Access Date: 10.07.2020).

[56]NIH, 2020.

GLWTechLLC. https://3dprint.nih.gov/discover/3dpx-013363-0. (Access Date: 10.07.2020).

[57]Vaňková E., Kašparová P., Khun J., Machková A., Julák J., Sláma M., Hodek J., Ulrychová L., Weber J., Obrová K., Kosulin K., Lion T., Scholtz V., 2020. Polylactic Acid as A Suitable Material For 3D Printing of Protective Masks in Times Of COVID-19 Pandemic. PeerJ https://doi.org/10.7717/peerj.10259.

[58]Leung W.W.F., Sun, Q., 2020. Electrostatic Charged Nanofiber Filter for Filtering Airborne Novel Coronavirus (COVID-19) And Nano-Aerosols. Separation and Purification Technology 116886, pp. 117.

[59]Pedro M., 2020. Filter Considerations in the COVID19 Era. https:/www.vyaire.com/sites/default/files/ 2020-06/vyr-gbl-2000294-filter-considerations-in-thecovid-19-era-wp_final.pdf. (Access Date: 10.10.2020).

[60]Ortiz L.W., Soderholm S.C., Valdez F.O., 1988. Penetration of Respirator Filters by An Asbestos Aerosol. American Industrial Hygiene Association Journal 49, pp. 451-460.

[61]Wilson A. M., Abney S. E., King M. F., Weir M. H., López-García M., Sexton J. D., Reynolds K. A., 1988. COVID-19 and Non-Traditional Mask Use: How Do Various Materials Compare in Reducing the Infection Risk for Mask Wearers? The Journal of Hospital Infection 105, pp. 640-642.
[62]Darnell M. E., Subbarao K., Feinstone S. M., Taylor D. R., 2004. Inactivation of The Coronavirus That Induces Severe Acute Respiratory Syndrome. Journal of Virological Methods 121, pp. 85-91. 